\title{
Rapid Weight Loss in Congolese Judo: Energy Profile, Performance and Haematological Effects
}

\section{Moulongo Jean Georges André ${ }^{*}$, Moussouami Simplice Innocent ${ }^{1}$, Moussoki Jean Martin ${ }^{1}$, Massala Kitanga Fêtra Nella ${ }^{1}$, Moulongo Ngwallat Jésus Amour Précieux ${ }^{1}$, Bueso Nzambi Ghislain Allure1,2, Ata Asiokarah Nel Francis², Diagne Ossey Marius², Packa Tchissambou Bernard1', Massamba Alphonse ${ }^{1}$}

${ }^{1}$ Research Unit of Combat Sports, Sports Biosciences Laboratory, Higher Institute of Physical and Sports Education, Marien Ngouabi University, Brazzaville, Congo

${ }^{2}$ Congolese Federation of Judo and Associated Disciplines, Brazzaville, Congo

Email: *jgamoulongo@gmail.com

How to cite this paper: André, M. J. G., Innocent, M. S., Martin, M. J., Nella, M. K. F., Précieux, M. N. J. A., Allure, B. N. G., Francis, A. A. N., Marius, D. O., Bernard, P. T., \& Alphonse, M. (2021). Rapid Weight Loss in Congolese Judo: Energy Profile, Performance and Haematological Effects. Advances in Physical Education, 11, 12-34. https://doi.org/10.4236/ape.2021.111002

Received: October 17, 2020

Accepted: December 27, 2020

Published: December 30, 2020

Copyright $\odot 2021$ by author(s) and Scientific Research Publishing Inc. This work is licensed under the Creative Commons Attribution International License (CC BY 4.0).

http://creativecommons.org/licenses/by/4.0/

\section{(c) (i) Open Access}

\begin{abstract}
While the deleterious effects of rapid weight loss (RWL) on the health in combat sports athletes are well known, the issue of exertion energy expenditure and motor performance remains controversial. The aim of this study was to investigate the impact of RWL on energy cost and judo performance, and associated haematological characteristics. Among 21 top Congolese judoists who took part in an intensive judo program lasting $51 / 2$ days (or 11 sessions), 16 of them rapidly lost $4 \%$ to $5.5 \%$ of body mass; corollarly with a reclassification in one of the 3 weight categories: $-60 \mathrm{~kg}(\mathrm{n}=7),-80 \mathrm{~kg}(\mathrm{n}=5)$ and $-100 \mathrm{~kg}(\mathrm{n}=4)$. During sessions 1 and 11 , the energy cost during the different training sequences was evaluated from the heart rate (HR). During the program, a judo performance test evaluated 2 performance indicators: the number of uchi-komi achieved and the height of uke's center of gravity during a throw. Basal blood parameters were determined before RWL and at $S_{1}$, $S_{11}$ (after the judo combat series). The results show a significant increase in heart rate from session $S_{1}$ to session $S_{11}$, in the different training sequences. HR after fights was around $98 \%$ of $\mathrm{HR}_{\max }$. In addition, a significant decrease in number of uchi-komi was observed on each of the bearings 4 to 6 and throughout the performance test, and in height of uke's center of gravity during fall movements. While most of the basal blood parameters remained unaltered during the program, red blood cell was reduced significantly and a significant plasma volume changes increase was found. The modification of each of the variables measured thus reflects the negative effect of the rapid weight loss associated to the increase in energy cost in judo.
\end{abstract}




\section{Keywords}

Rapid Weight Loss, Judo, Heart Rate, Performance, Basal Blood Parameters

\section{Introduction}

The Olympic disciplines of combat sports (i.e., judo, wrestling, taekwondo and boxing) account for almost $25 \%$ of the total medals disputed in the Olympic Games (Gutierrez-Garcia et al., 2010). Judo is a martial art and Olympic sport comprising standing and ground fighting. It interred the Olympic program in 1964 as a demonstrative sport in Tokyo, Japan and officially in 1972 for men during Olympic Games in Munich, Germany, and 1992 for women. During competitions, judo athletes (or judoists) are divided by sex, sometimes by grade or judo experience, and organized in age class and weight divisions (categories) (Pocecco \& Burtscher, 2013). Nowadays, judo ranks among the most popular Asian martial arts in the world (Gutierrez-Garcia et al., 2010). The judo can be characterized as high-intensity, intermittent activity (Franchini et al., 2011a) and consequential adaptations are consistently found in judoists (Franchini et al., 2011b). In competition, judo is characterized by fights between two athletes of the same weight category. A judo fight lasts in actual time, from the junior categories, 5 minutes for men and 4 for women. This total time is made up of several combat sequences, with an average duration of $22 \pm 10 \mathrm{~s}$ for juniors and $33 \pm 30$ s for seniors (Miarka et al., 2012). These assault sequences are interspersed with recovery sequences of 7 to 15 seconds because we are witnessing a succession of effort times of 20 - $40 \mathrm{~s}$ interspersed with pauses of 10 - $15 \mathrm{~s}$ (Favre-Juvin et al., 1989; Paillard, 2010). This type of profile strongly solicits anaerobic processes during intense and maximum efforts, verified by high blood lactate concentrations (Maillat \& Gaillat, 1987); but also, aerobic processes to last the duration of the fight and to recover efforts during periods of recovery or lower intensity (Paillard, 2010). This author emphasizes that aerobic metabolism, including maximum oxygen uptake $\left(\mathrm{VO}_{2 \max }\right)$, maximum strength, and especially anaerobic power (explosiveness) are major factors of performance in judo. In addition, the work of Muller Deck (1987) and some studies on the energy profile by spectroscopy (Gariod et al., 1995) show two profiles of judo fighters: an explosive profile (judoist winner of a fight at the start of the assaults) and an enduring profile (judoist winning the fights rather at the end). The physiological requirements of judo vary according to these profiles and weight categories, which follow in the men: $-60 \mathrm{~kg},-66 \mathrm{~kg},-73 \mathrm{~kg},-81 \mathrm{~kg},-90 \mathrm{~kg},-100 \mathrm{~kg},+100 \mathrm{~kg}$ (IJF, 2020). This is why the term of weight category is attached to weight loss. Indeed, the majority of athletes reduce their body mass in order to fight in a lower weight category, this being perceived as "an advantage in competition against an opponent of a lighter weight category" (Artioli et al., 2010). It would seem necessary for ath- 
letes to maintain their weight sustainably throughout the sporting season, but this is scarcely the case. Thus, weight loss is an entire part of judo as a competitive weight class sport, like all combat sports.

In the judo world, "weight loss often resonates with increased performance" (Schaffter, 2004): fighters practice it in order to be opposed to "smaller and weaker opponents" (Brito et al., 2012). For this, they often practice it unreasonably, without the help of qualified coaches. For example, Artioli et al. (2010) report that the most influential people in relation to the weight loss management behaviors of a judoist are his trainer (23.7\%) and another judoist (20.6\%); the dietitian nutritionist is cited only in sixth place (7.3\%). However, it can be safely assumed that the majority of coaches and judoists are not qualified to supervise these practices. Moreover, Franchini et al. (2012), in a large review of the Medline, Lilacs, PubMed and SciElo databases, note that $60 \%$ to $90 \%$ of fighters, and $90 \%$ of judoists have already practiced rapid weight loss, that is to say spread over 10 days maximum. They also note that $40 \%$ of judoists had already lost more than $5 \%$ of body mass at least once, with, in most cases, rapid weight loss (RWL). One of the techniques associated to judo RWL is increased physical activity, with a frequency of $90 \%$ according to Brito et al. (2012).

Franchini et al. (2012) find different effects of RWL on performance in judo. The effects are primarily psychological: decrease in self-esteem and increase in confusion, nervousness and depression, due to fatigue attributed to the restriction of energy intake mainly (Degoutte et al., 2006). Brito et al. (2012) report similar effects in their review of the literature, also based on studies specific to combat sports: decreased concentration, short-term memory, and the speed of cognitive processing. Cognitive functions are altered with the decrease in blood glucose caused by the restriction of energy intake (Choma, 1998). The effects of RWL on performance and health are also well known, particularly: decrease in aerobic and anaerobic performance (Fogelholm, 1994), attributed to decreased plasma volume; increased risk of injury (Green, 2007); alteration of thermoregulatory processes (Yang et al., 2017; Koral \& Dosseville, 2009), consequence of dehydration (linked to restriction of fluid intake and the search for weight loss through sweating, when this is the case); decreased anaerobic performance: reduced anaerobic power, anaerobic capacity and maximal strength (except maximal lower limb strength which does not appear to be anaerobic) (Webster et al., 1990). The reduction in aerobic and anaerobic performance can be attributed to the decrease in plasma volume and glycogenic depletion linked respectively to the restriction of water and energy intake (Fogelholm, 1994). In addition, previous studies indicated that RWL increases oxidative stress, leads to an imbalance of electrolytes and hormones, changes in blood flow, and decreases plasma volume (Costill et al, 1976; Oppliger et al, 1996; Sawka \& Pandolf, 1990). The literature review also reports that dehydration following rapid weight loss is characterized by hyperosmolarity which increases blood viscosity, which can alter the ventilation/pulmonary perfusion 
ratio and therefore the oxygen transport capacity at the cellular level (Caldwell et al., 1984). The RWL technique therefore requires the judoist to drink a lot after the competition to restore his water balance and eliminate his overproduction of uric acid. However, this compensatory phase is never complete in the short term (Shephard \& Shek, 1995). In fact, several days after the competition, the athlete still presents physiological sequelae inherent in this transient water manipulation. This manifests itself in a mineral loss which impairs his physical capacities and his faculties of recovery. In addition, analyzing some studies implies a difference between physical performance in laboratory tests and athletic performance in real competition after RWL. Strength, power, $\mathrm{VO}_{2 \max }$, and anaerobic performance measured on the one hand in a vertical jump test (Viitasalo et al., 1987), and on the other hand in a Wingate test (Serfass et al., 1984; Reljic et al., 2016; Fogelholm et al., 1993), were not affected by WRL. These appear to be controversially discussed because of percentages of RWL and various measurements of athletic performance (Serfass et al., 1984). All of these factors mentioned above represent limits to athletic performance. Moreover, from aforementioned it is not clear if and how RWL affects judo-specific performance but also blood basal parameters and lactatemia during and after consecutive judo fights. However, Paillard (2010) suggests that these limits would appear for rapid weight loss from $4 \%$ to $6 \%$ of body mass. In addition, the increase in energy cost is contradictory with sharpening, a period consisting in a reduction in the volume of training before a competition whose aim is to optimize performance on the D-day. Indeed, this period of sharpening causes different adaptations: increase in strength and power, possibly due to changes in contractile properties in muscle fibers; repair of tissue damage; recharging of energy stores of glycogen (Klissouras, 2017).

In view of the scarcity of studies which have objective this hypothesis among judoists, we considered it important and necessary to undertake this work in Congo-Brazzaville to test this hypothesis. Indeed, in Congo where judo is now the fifth most practiced sport with 6 participations in the Olympic Games (FECOJU, 2018), RWL by increasing judo activity is the most common technique. In view of the constant deterioration of living conditions and the ever-increasing poverty of the social strata from which the majority of judoists come (PNUD, 2018; WHO, 2018), this practice can only accentuate this negative impact. In addition, to our knowledge, no study has shown the effects of RWL on judo performance assessed by a field test. To this end, the purpose of the present investigation was to test the hypothesis of Paillard (2010), with the following objectives: identify weight loss practices beyond the increased energy expenditure associated with the intensive practice of judo; estimate and analyze the energy expenditure of Congolese judoists during a judo session during a period of $51 / 2$ days of intensive judo training for a weight loss of about $5 \%$; determine and examine the associated physiological and haematological responses, depending on the weight category. 


\section{Materials and Methods}

\subsection{Participants}

A total of 21 male judoists (black belt, degree: $1^{\text {st }}$ dan to $3^{\text {rd }}$ dan) volunteered to take part in this observational and experimental study. Aged 19 to 26 years (mean age: $22.3 \pm 1.5$ years), they belonged to the $-66 \mathrm{~kg}(\mathrm{n}=10),-90 \mathrm{~kg}(\mathrm{n}=$ $7)$ and $+100 \mathrm{~kg}(\mathrm{n}=4)$ weight categories; they wanted to move to the next lower weight category: $-60 \mathrm{~kg},-81 \mathrm{~kg}$ and $-100 \mathrm{~kg}$. These judoists were competitors accustomed to performing rapid weight losses such as the one used in this study. Only any judoist was included in this work: no smoker; no having consumed alcohol in the last 24 hours before the experiment; without cardiorespiratory and haematological pathology; familiar with the practice of rapid weight loss; no having a competitive deadline close to the protocol followed for the study so as not to interfere with his athletic performance. The anthropometric characteristics of the subjects before the implementation of the program are shown in Table 1.

The study was approved by the National Commission of Ethics for Research in Health Sciences (CNERSSA) of the General Delegation of Scientific and Technological Research, Ministry of Scientific Research and Technological Innovation of Congo Brazzaville. The protocols applied during this experiment complied with the Declaration of Helsinki II. All participants signed a written consent form.

\subsection{Study Design}

The study took place in February 2020 in a modern gymnasium including a dojo (judo room). The body mass loss objective set at $4 \%-5.5 \%$ in these $51 / 2$ day works, corresponded to the average objective set by judoists practicing a state of dehydration in the studies by Yang et al. (2017), Brito et al. (2012). During this period, those subjects wishing to change weight class were asked to adopt their individual weight loss methods. During this period selected for the intensive program of judo practice, the training volume was 11 sessions $\left(\mathrm{S}_{1}, \mathrm{~S}_{2}, \ldots, \mathrm{S}_{11}\right)$ at a rate of 3 hours in the morning ( 9 a.m. - 12 p.m.) and 2 hours in the afternoon (3 p.m. - 5 p.m.), for a total of 28 hours, Monday to Saturday morning. A session was made up of 3 parts: warm-up + physical preparation (general and specific), technical-tactical training and successive randoris (fights), recovery + debriefing.

Table 1. Anthropometric data of subjects before the rapid weight loss program.

\begin{tabular}{ccccc}
\hline & $\begin{array}{c}\text { All group } \\
(\mathbf{n}=21)\end{array}$ & $\begin{array}{c}-66 \mathrm{~kg} \\
(\mathbf{n}=10)\end{array}$ & $\begin{array}{c}-90 \mathrm{~kg} \\
(\mathbf{n}=7)\end{array}$ & $\begin{array}{c}+100 \mathrm{~kg} \\
(\mathbf{n}=4)\end{array}$ \\
\hline Age (years) & $22.3 \pm 1.5$ & $20.5 \pm 0.8$ & $21.7 \pm 2.1$ & $24.7 \pm 1.6$ \\
Height $(\mathrm{cm})$ & $175.68 \pm 1.86$ & $173.41 \pm 2.05$ & $175.23 \pm 1.41$ & $178.41 \pm 2.12$ \\
Weight $(\mathrm{kg})$ & $82.23 \pm 1.86$ & $62.01 \pm 0.14$ & $81.35 \pm 1.06$ & $102.58 \pm 0.37$ \\
BMI $\left(\mathrm{kg} / \mathrm{m}^{2}\right)$ & $26.79 \pm 0.48$ & $21.00 \pm 0.03$ & $26.58 \pm 1.04$ & $32.78 \pm 0.36$ \\
\hline
\end{tabular}

BMI: Body mass index. 
The physical preparation began with 5 minutes of cardiovascular activation exercises, followed by a joint and muscle warm-up (10 minutes), a specific judo warm-up (10 minutes) and specific judo weight-training exercises (20 minutes). The technical-tactical training, meanwhile, was based on: uchi-komi (duration: 20 - 25 minutes), tandoku-reiku; ne-waza (ground work). As for the fights whose number varied from 5 to 7 per judoist with various partners, their duration was in accordance with the recommendations of the International Judo Federation (IFJ) and their intensity was around $80 \%-95 \%$ of the $\mathrm{HR}_{\max }$. Recovery consisted of muscle and cardiorespiratory relaxation exercises, as well as meditation exercises based on Zen Buddhism. On the first day of the experiment, height and body mass measurements were taken $45 \mathrm{~min}$ before the $\mathrm{S}_{1}$ session, followed by the heart rate at rest $\left(\mathrm{HR}_{0}\right)$. Subsequently, haematological and $\mathrm{HR}$ measurements were taken at the end of the technical-tactical period, precisely after the phase of judo fights. The same procedure was followed during session $S_{11}$. Regarding the parameters of interest associated with the performance mortice, the subjects were subjected to the test of Almansba et al. (2007) for the determination of the quantity and the quality of execution of a technical judo gesture.

\subsection{Anthropometric Measurements}

Body mass was measured to the nearest $100 \mathrm{~g}$ using an electronic balance (Omron Health Care), with the subjects wearing only shirts without shoes. Standing height was measured to the nearest $0.1 \mathrm{~cm}$ using a stadiometer (Seca Instruments Ltd, Hamburg, Germany). Body mass index (BMI) was calculated using the formula: Weight $(\mathrm{kg}) /[\text { Height }(\mathrm{m})]^{2}$.

\subsection{Physiological Measurements}

They boiled down to heart rate (HR). A polar Pro Team dock (Polar Electro OY, Finland) was used to record heart rate. Apart from its collection during sessions $S_{1}$ and $S_{11}$, it was also recorded after the warm-up.

\subsection{Blood Collection and Analyses}

Blood samples were assessed pre-sequence $S_{1}$ and immediately after $S_{1}$, as well as immediately after $S_{5}$ and $S_{11}$ sequences. On the day of sequence, the judoists arrived at the place of experimentation after an overweight fast between 10:00-12:00. A resting blood sample was taken after the subjects had been standing for at least 15 min, after which the participants consumed a light standardized meal and drink at rest for $2 \mathrm{~h}$. The meal consisted of $1.7 \mathrm{~g}$ white bread and $0.3 \mathrm{~g}$ of a low-fast spread; both values are per kilogram of body mass (Redman et al., 2007). Consumption of coffee, tea, alcohol and other beverages containing coffeine $3 \mathrm{~h}$ before testing was not permitted. In addition, all subjects did not perform any exercise for the last $72 \mathrm{~h}$. Venous blood was sampled from an elbow vein into sodium-heparin tubes (BD Vacutainer, USA) to measure basal blood parameters included: red blood cell concentration (RBC), hemoglobin concen- 
tration $(\mathrm{Hb})$, hematocrit $(\mathrm{Hct})$, mean corpuscular volume (MCV), mean corpuscular hemoglobin $(\mathrm{MCH})$, mean corpuscular hemoglobin concentration (MCHC) and were measured using an automated analyzer (MS9-Melet Shoesing Laboratories, Osny, France) according the manufacturer's protocol. Changes in $\mathrm{Hb}$ concentration and Hct levels were used to calculate in plasma volume changes ( $\triangle \mathrm{PV})$ according to Dill and Costill's (1974) formula:

$$
\% \Delta \mathrm{PV}=100 \times\left[\mathrm{Hb}_{0} / \mathrm{Hb}_{1} \times\left(1-\mathrm{Hct}_{1} \times 10^{-2}\right) /\left(1-\mathrm{Hct}_{0} \times 10^{-2}\right)\right]-100
$$

where 0 refers to resting values (before the period of judo fights) for $\mathrm{Hct}$ and $\mathrm{Hb}$, and 1 refers to the subsequent values for $\mathrm{Hct}$ and $\mathrm{Hb}$ after the period of judo fights.

Capillary blood was additionally sampled from the earlobe at rest, and after $S_{1}$ and $S_{11}$ sequences into heparinized capillaries (EKF Diagnostics GmbH, Germany) to measure lactate concentration by an enzymatic-amperometric sensor chip system (Biosen S-line, EKF diagnostic sales, GmbH, Germany).

\subsection{Physical Fitness}

Energy expenditure during a judo session was evaluated from the heart rate (HR) recorded at the end of each session. It was measured using a telemetry device (Polar Pro Team dock), with continuous recording. We have used the highest and lowest HR during each phase of training in order to quantify the level of cardiac demand of each. The Almansba et al. (2007) fitness test to which the subjects were subjected, is a field test that takes place over 6 bearings. It has 3 phases: isometric phase, shuttle phase, and recovery phase as shown in Table 2.

During the isometric phase, the judoist exerts a pulling force on a jacket of a judogi attached to a rubber band with a resistance of $50 \mathrm{~kg}$. The goal of each subject during the test is to perform as many uchi-komi as possible while maintaining the highest possible quality of execution. Figure 1 illustrates the installation of the required equipment within the test site for the conduct of the test.

Points A (partner) and B (marker on the ground) are located 3 meters apart, between which the subject goes back and forth for the dynamic phase. During the test, for each of the six bearings are recorded: the number of uchi-komi performed, and the height $\mathrm{H}$ (in $\mathrm{cm}$ ) at which uke's center of gravity (who undergoes the movement) is located, determined from a video analysis (JVC GC-PX10 $\mathrm{HD}$ camera) as the difference $\mathrm{H}$ between the maximum height $\mathrm{h}_{1}$ and the initial height $\mathrm{h}_{0}$ of the center of gravity. For this, luminescent pellets have been placed on the judogi jackets to materialize the position of the center of gravity.

Table 2. Protocol of the performance test of Almansba et al.

\begin{tabular}{ccccccc}
\hline & Bearing 1 & Bearing 2 & Bearing 3 & Bearing 4 & Bearing 5 & Bearing 6 \\
\hline Isometric phase & $3^{\prime \prime}$ & $6^{\prime \prime}$ & $9^{\prime \prime}$ & $12^{\prime \prime}$ & $15^{\prime \prime}$ & $18^{\prime \prime}$ \\
Shuttle phase & $20^{\prime \prime}$ & $20^{\prime \prime}$ & $20^{\prime \prime}$ & $20^{\prime \prime}$ & $20^{\prime \prime}$ & $20^{\prime \prime}$ \\
Recovery phase & $4^{\prime \prime}$ & $6^{\prime \prime}$ & $8^{\prime \prime}$ & $10^{\prime \prime}$ & $12^{\prime \prime}$ & \\
\hline
\end{tabular}

Source: Almansba et al. (2007). 


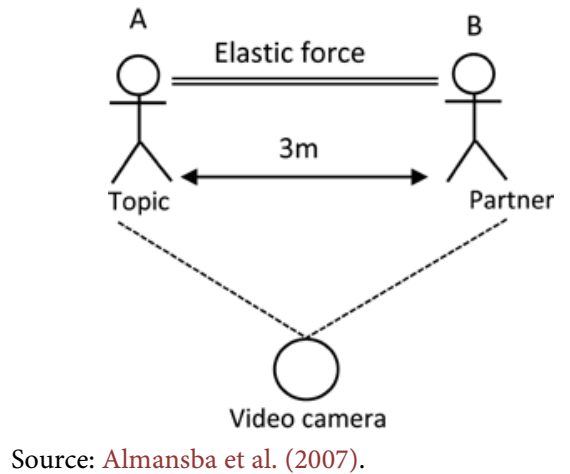

Figure 1. Performance test hardware installation.

Thus, the Almansba test made it possible to determine the number of uchi-komi with projection performed by Tori (globally and by level) and the height of the center of gravity of the projected partner (uke) at the end of each level (thus translating Tori's fatigue). The measures of these performance indicators were taken before the blood samples collection: 1) during sessions $S_{1}$ and $\mathrm{S}_{11}$ according to the weight categories and the level for the uchi-komi; 2) bearings 1 to 11 , and sessions 1 and 11 for the height of the center of gravity of uke.

\subsection{Statistical Analysis}

All anthropometric and haematological variables (RBC, $\mathrm{MCH}, \mathrm{MHCH}, \mathrm{Hb}, \mathrm{Hct}$, $\Delta \mathrm{VP}$ ) of the study were assessed at the start of the program, at the end of the technical-tactical and period of each serie of fights, second set and third set, as well as between sessions 1 and 11. Regarding the variables associated with performance in the test of Almansba et al., they were: heart rate; number of uchi-komi performed at each level; height of the center of gravity at each session. A few parameters were evaluated in the judoists according to their profile. Data are expressed either as frequencies and percentages, or as mean \pm SD. The normality of the data distribution was verified using the Shapiro-Wilk test. The comparison of two means used Student's t test; In the event of normality, the Wilcoxon test was applied. Spiegel's test was used to compare two percentages. The data were analyzed using an Anova (time $\times$ group) to compare the end-of-effort HR values, from the warm-up period to the fighting phase through the period of physical preparation. On the other hand, it was the end of sessions $S_{1}, S_{5}$ and $S_{11}$ for 3 performance indicators of Almansba and al., and haematological parameters. If statistically significant, Tukey's post hoc test was used to locate the level of difference. Sokal and Rohlf (1995) was used to compare 3 percentages. $p<0.05$ was used as the statistical significance level.

\section{Results}

\subsection{Weight Data and Weight Loss Practices}

Among the 21 subjects selected, only 16 of them lost a weight between $4 \%-5.5 \%$ (Table 3). These were 7 subjects who were in the $-66 \mathrm{~kg}$ to $-60 \mathrm{~kg}$ category (i.e. 
Table 3. Weight variations of subjects included in the study.

\begin{tabular}{ccccccc}
\hline \multirow{2}{*}{ Subject } & \multicolumn{2}{c}{ From -66 to -60 kg } & \multicolumn{2}{c}{ From -90 to -81 kg } & \multicolumn{2}{c}{ From +100 to -100 kg } \\
\cline { 2 - 6 } & Pi (kg) & Pf (kg) & Pi (kg) & Pf (kg) & Pi (kg) & Pf (kg) \\
\hline 1 & 61.5 & 58.6 & 82.3 & 78.7 & 103.5 & 98.1 \\
2 & 62.7 & 59.5 & 81.7 & 77.6 & 103.1 & 97.7 \\
3 & 62.3 & 59.8 & 82.5 & 78.2 & 102.6 & 97.4 \\
4 & 61.8 & 58.5 & 82.2 & 78.7 & 101.9 & 97.6 \\
5 & 62.1 & 59.2 & 81.8 & 77.5 & --- & --- \\
6 & 61.7 & 58.1 & --- & --- & --- & --- \\
7 & 62.2 & 59.2 & --- & --- & --- & --- \\
Mean (kg) & 62.0 & 59.0 & 82.1 & 78.3 & 102.7 & 97.7 \\
SD (kg) & & 0.6 & & 0.6 & & 0.3 \\
$\Delta \mathrm{P}(\mathrm{kg})$ & & 3.1 & & 3.9 & & 5.2 \\
$\Delta \mathrm{P}(\%)$ & & 4.9 & & 4.8 & & 5.0 \\
\hline
\end{tabular}

Abbreviations: $\mathrm{Pi}$, initial weight before the weight loss program; Pf, final weight at the end of the program; $\Delta \mathrm{P}$, weight variation induced by the program; $\mathrm{SD}$, standard deviation

$70 \%$ of cases), 5 subjects in the $-90 \mathrm{~kg}$ to $-81 \mathrm{~kg}$ category ( $7.4 \%$ of cases) and 4 out of four subjects from $+100 \mathrm{~kg}$ to $-100 \mathrm{~kg}$ category (100\% of cases). The mean weight loss was $3.1 \mathrm{~kg}$ in the $-60 \mathrm{~kg}$ category (range: $2.5 \mathrm{~kg}-3.6 \mathrm{~kg}$ ); it was $4.0 \mathrm{~kg}$ in subjects weighing less than $81 \mathrm{~kg}$ (range: $3.5-4.3 \mathrm{~kg}$ ), and $5.2 \mathrm{~kg}$ for less than $100 \mathrm{~kg}$ (range: $4.3-6 \mathrm{~kg}$ ). Among the weight loss practices combined with increased energy expenditure in judo, the data collected from interviews with the judoists revealed, in decreasing order of importance: restriction of food intake, $61 \%$ of quotes; drastic restriction of specific intakes, $35 \%$; restriction of water intake, $20 \%$ for an average intake of $0.5 \mathrm{~L}$ during the program; the increase in energy expenditure combined with the practice of long jogging, 17\%; laxatives and diuretics, $3 \%$.

\subsection{Energetic Cost}

Figure 2 illustrates the change in heart rate at the start of the program during the different training sequences within each weight category. The resting HR values were: $63.1 \pm 2.4 \mathrm{bpm}$ in the $-60 \mathrm{~kg}$ judoists, $64.5 \pm 2.2 \mathrm{bpm}$ in those under $81 \mathrm{~kg}$ and $60.3 \pm 1.8 \mathrm{bpm}$ in the less than $100 \mathrm{~kg}$. The energy expenditure requested in the fights decreased between sessions $S_{1}, S_{5}$ and $S_{11}$; the highest $\mathrm{HR}_{\max }$ was noted during session $S_{1}: 173.1 \pm 10.2 \mathrm{bpm}$ in judoists with $-60 \mathrm{~kg}$ versus $169.5 \pm 13.0 \mathrm{bpm}$ in those weighing $-81 \mathrm{~kg}$ and $166.4 \pm 10.6 \mathrm{bpm}$ for judoists under $100 \mathrm{~kg}$. $\mathrm{HR}_{\max }$ values after weight loss were higher than those found before the program.

Heart rate varied throughout each training phase. During the warm-up, the highest HRs were between $70 \%-90 \%$ of the subject's $\mathrm{HR}_{\max }$. Throughout the warm-ups, HR was not less than $70 \%$ of $\mathrm{HR}_{\max }$. During the technical-tactical 


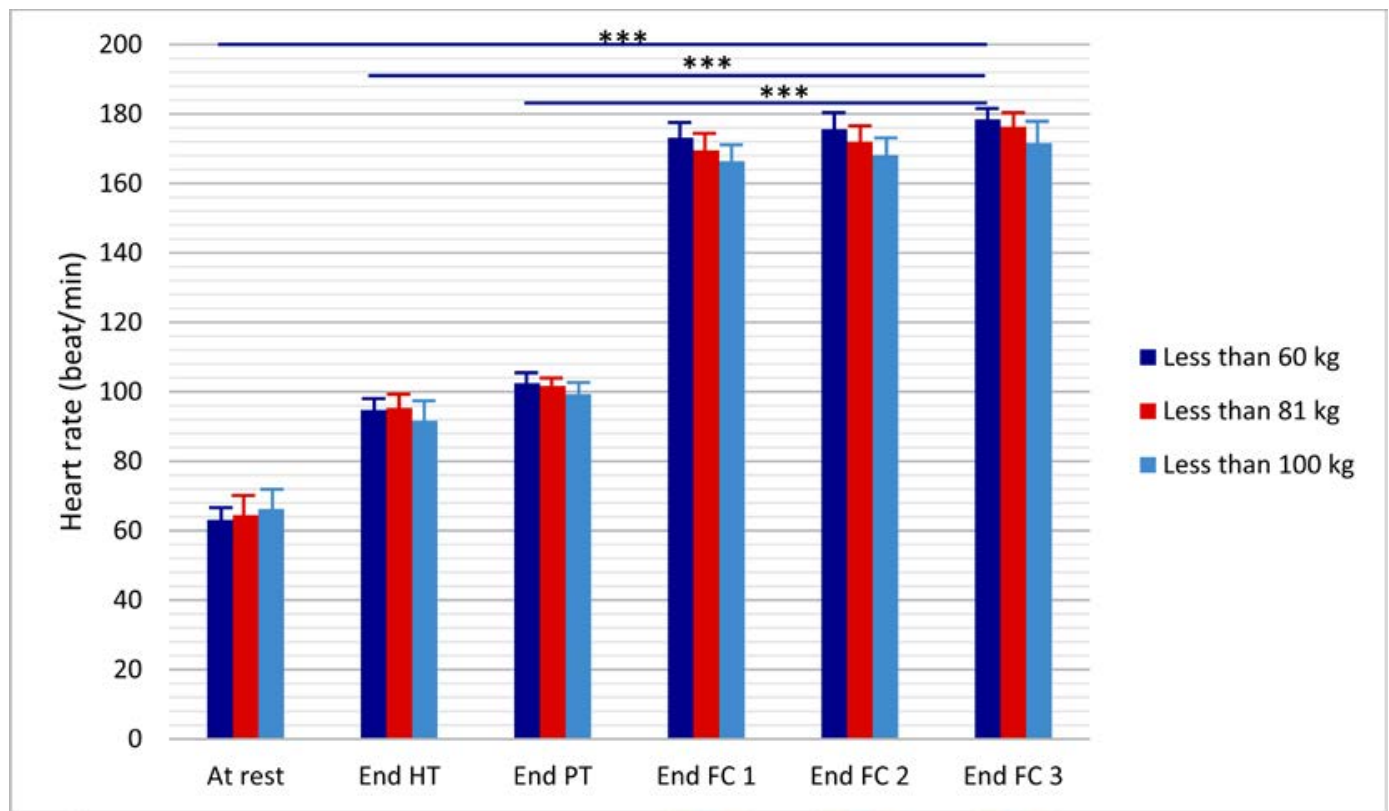

Legend: End HT, at the end of the warm-up; End PT, at the end of physical preparation; End FC1, at the end of the first series of fights; End FC2, at the end of the second series of fights; End FC3, at the end of the third series of fights.

Figure 2. Evolution of exercise heart rate in the three weight categories in session 1.

period, the highest HRs were between $80 \%-100 \%$ of the $\mathrm{HR}_{\max }$, the lowest between $80 \%-90 \%$ of the $\mathrm{HR}_{\max }$. Following the judo fights, the $\mathrm{HR}_{\max }$ were close to the subject's $\mathrm{HR}_{\max }: 180 \mathrm{bpm}\left(98 \%\right.$ of $\left.\mathrm{HR}_{\max }\right)$. Therefore, the movements undertaken during these confrontations resulted in a cardiac solicitation of $80 \%$ to $100 \%$ of the $\mathrm{HR}_{\max }$; the lowest $\left(60 \%\right.$ of $\left.\mathrm{HR}_{\max }\right)$ were noted during periods of recovery often linked to the award of numerous penalties (faults) from the partner or the subject himself.

At the end of the $11^{\text {th }}$ session and following the subjects' weight loss, the raw heart rates increased compared to those noted in session $S_{1}$ in the new weight categories (Figure 3). A significant difference was during the different phases of the training sessions: $66.8 \pm 1.8 \mathrm{bpm}$ at rest $v s 97.4 \pm 3.5 \mathrm{bpm}$ at the end of the warm-up vs $180.5 \pm 4.9 \mathrm{bpm}$ at the end fight $[\mathrm{F}(2,18)=1656.93 ; p<0.001]$. High HR values were found in subjects less than $60 \mathrm{~kg}$, followed by those noted in subjects less than $81 \mathrm{~kg}$.

\subsection{Motor Performance}

The difference in the number of uchi-komi performed by subjects for all weight categories was significant for four of the 6 bearings, from third bearing, respectively: $p=0.035, p=0.011, p=0.007$ (Figure 4). The highest number of uchi-komi was found before the implementation of the program. Corollarly, the total number of uchi-komi achieved by all subjects was noted at the start of the intensive judo program combined with weight loss.

The same was true for the change in the average height $\mathrm{H}$ at which uke's center of gravity was located during the execution of the movement (Figure 5). The 


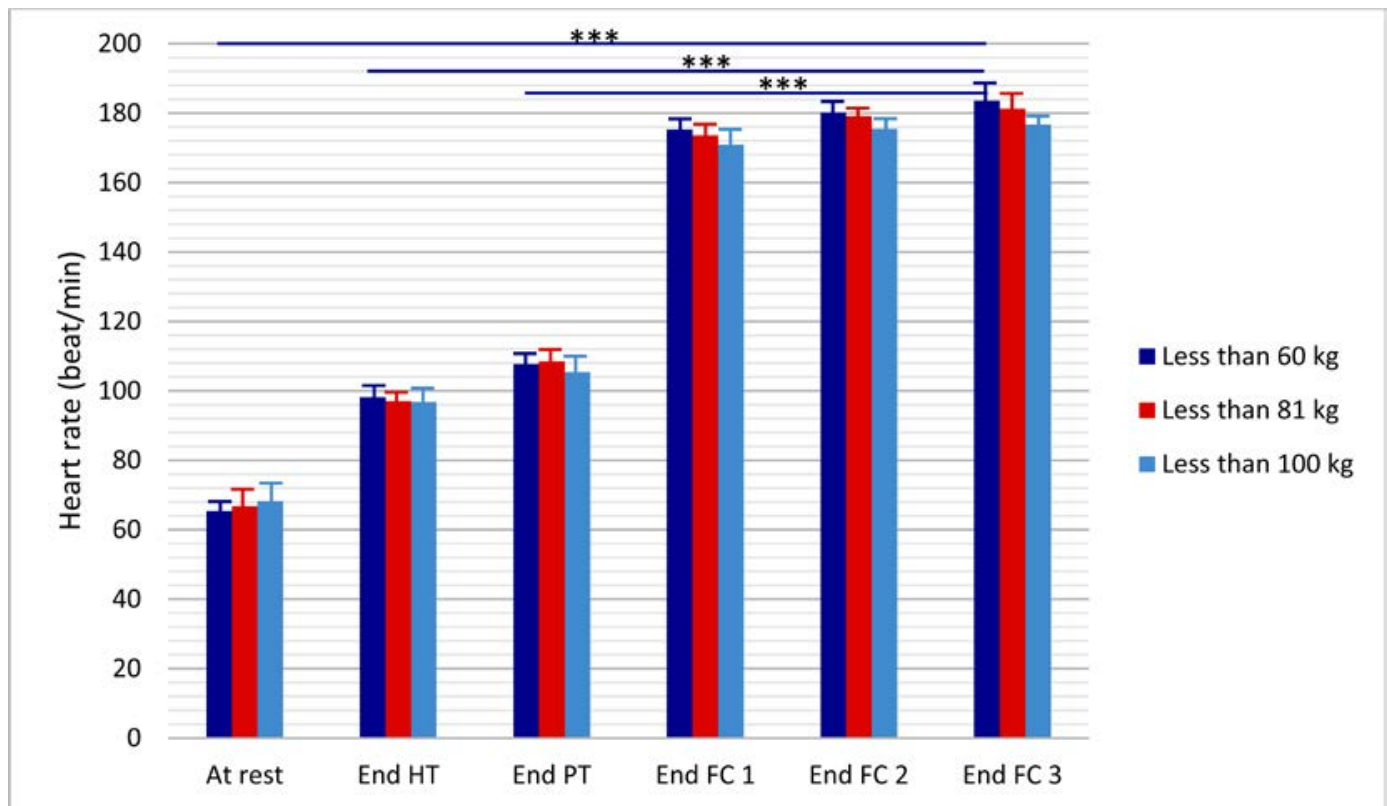

Legend: End HT, at the end of the warm-up; End PT, at the end of physical preparation; End FC1, at the end of the first series of fights; End FC2, at the end of the second round of fights; End FC3, at the end of the third series of fights.

Figure 3. Evolution of exercise heart rate in the three weight categories in session 11.

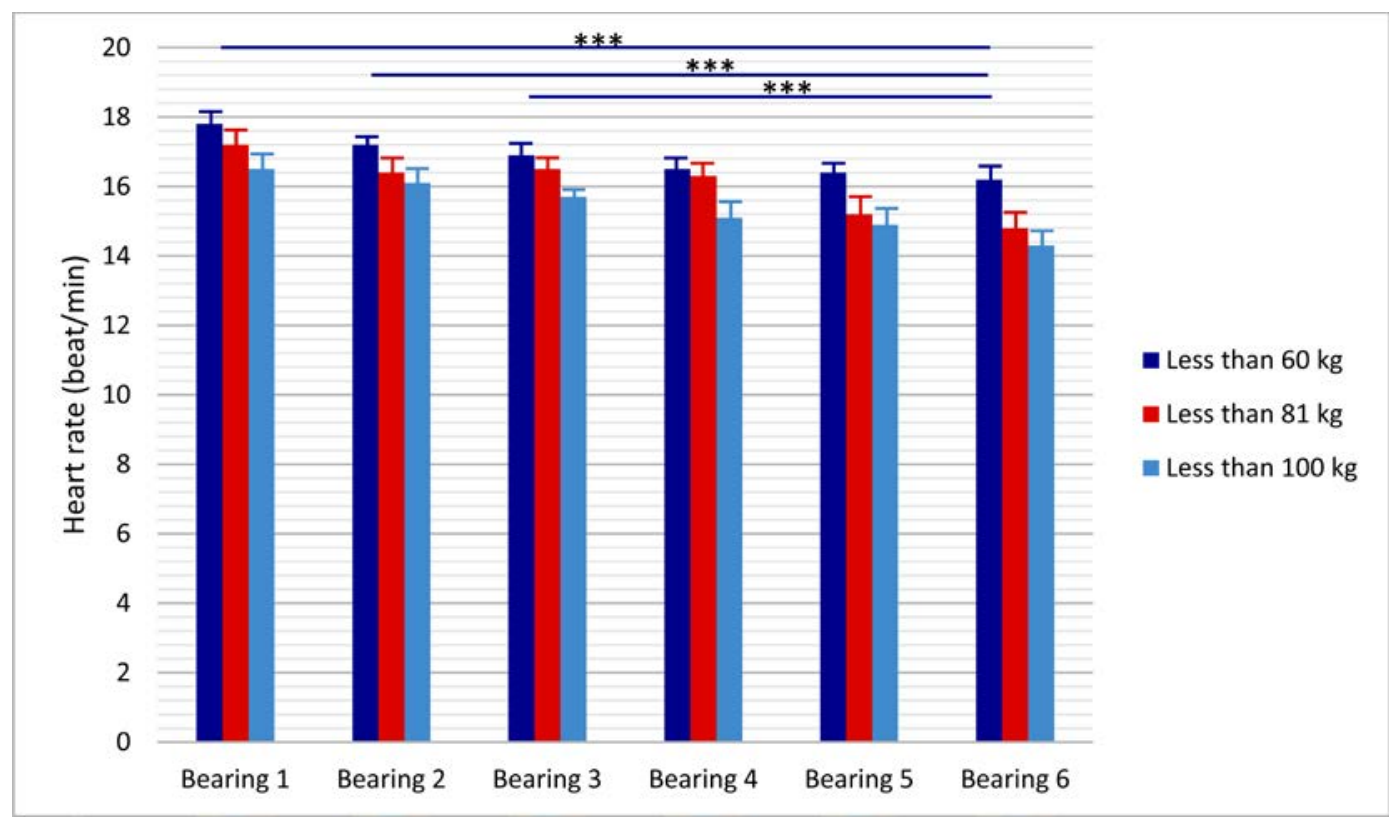

Figure 4. Evolution of the average number of uchi-komi per bearing in all subjects during the program.

difference between the mean heights for each bearing, recorded in the sessions 1 and 11, was significant, from bearing 1 to the eleventh session: $p=0.041$ from bearing 1 to bearing $4, p=0.023$ from bearing 1 to bearing 5 and $p=0.007$ from bearing 1 to bearing 6 .

\subsection{Evolution of Haematological Values}

The evolution of basal blood parameters is presented in Table 4. The hematocrit 


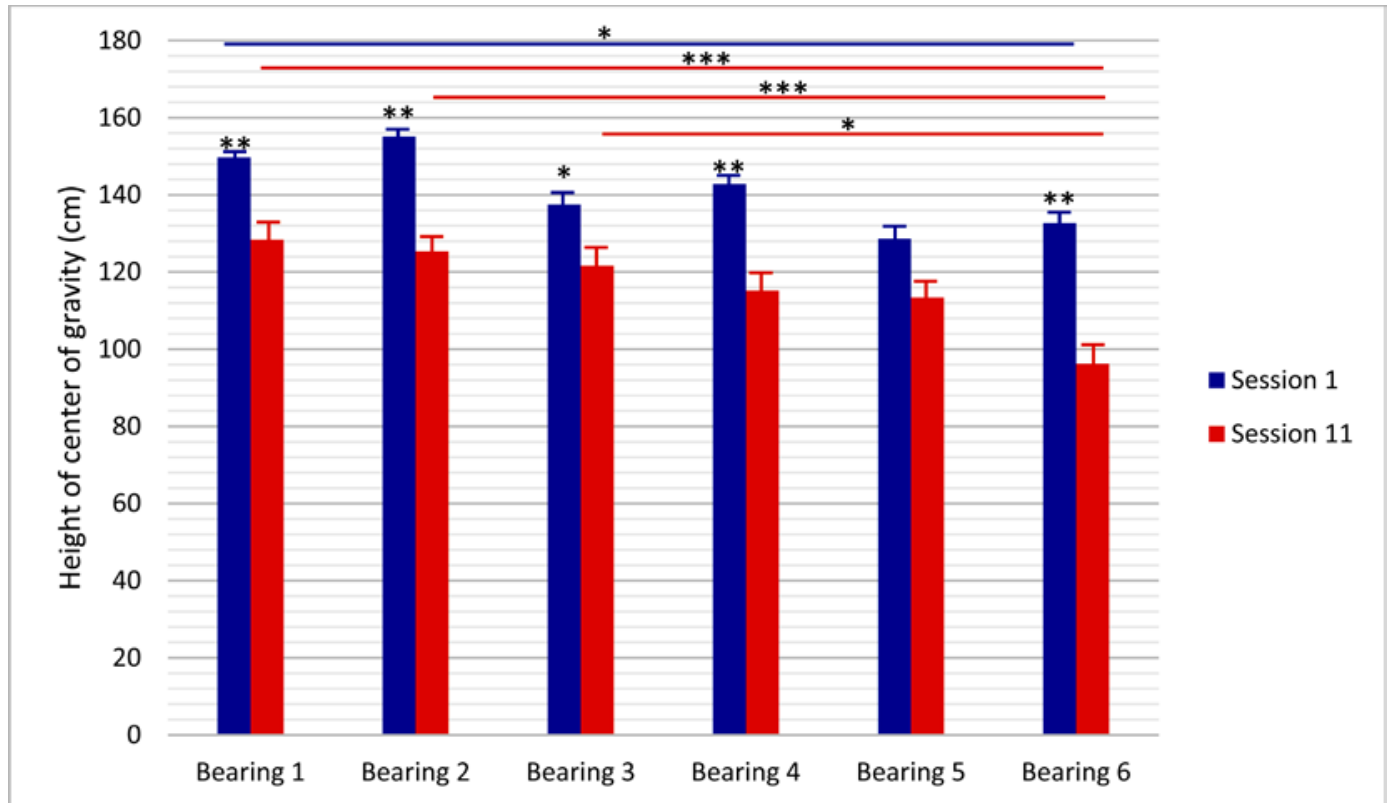

Figure 5. Evolution of the height $\mathrm{H}$ of the center of gravity in bearings in the 3 weight categories during the program.

Table 4. Haematological and biochemical data of all subjects.

\begin{tabular}{ccccc}
\hline & $\begin{array}{c}\text { Before RWL } \\
(\mathbf{n}=16)\end{array}$ & $\begin{array}{c}{\text { After } \mathrm{JFS}_{1}}_{(\mathbf{n}=16)} \\
\text { After } \mathrm{JFS}_{11} \\
(\mathbf{n}=16)\end{array}$ & $\boldsymbol{P}$ \\
\hline $\mathrm{RBC}\left({ }^{*} 10^{6} / \mu \mathrm{L}\right)$ & $5.84 \pm 0.35$ & $5.35 \pm 0.23$ & $5.22 \pm 0.16$ & $<0.001$ \\
$\mathrm{Hb}(\mathrm{g} / \mathrm{dL})$ & $17.91 \pm 0.82$ & $15.92 \pm 0.57$ & $15.28 \pm 0.74$ & $\mathrm{NS}$ \\
$\mathrm{Hct}(\%)$ & $49.74 \pm 1.64$ & $47.26 \pm 1.34$ & $43.52 \pm 2.06$ & $<0.001$ \\
$\Delta \mathrm{VP}(\%)$ & 100 & $118.05 \pm 5.20$ & $131.48 \pm 3.70$ & $<0.05$ \\
$\mathrm{MCV}(\mathrm{fl})$ & $84.92 \pm 2.73$ & $85.37 \pm 2.81$ & $85.70 \pm 3.15$ & NS \\
$\mathrm{MCH}(\mathrm{pg})$ & $30.38 \pm 1.65$ & $29.52 \pm 1.76$ & $30.16 \pm 1.83$ & $\mathrm{NS}$ \\
$\mathrm{MCHC}(\mathrm{g} / \mathrm{dL})$ & $35.66 \pm 1.08$ & $34.64 \pm 0.95$ & $35.22 \pm 1.60$ & $\mathrm{NS}$ \\
$\mathrm{Peak}[\mathrm{La}](\mathrm{mmol} / \mathrm{L}$ & $1.73 \pm 0.12$ & $9.61 \pm 0.74$ & $8.32 \pm 2.54$ & NS \\
\hline
\end{tabular}

Abbreviations: JFS, judo fight sequence; RBC, red blood cell, Hb, hemoglobin; Hct, hematocrit; PV, plasma volume; $\mathrm{MCV}$, mean corpuscular volume; $\mathrm{MCH}$, mean corpuscular hemoglobin; $\mathrm{MCHC}$, mean corpuscular hemoglobin concentration; Peak [La], highest lactate concentration; RWL, rapid weight loss.

concentration was significantly lower at the $11^{\text {th }}$ judo fight sequence compared at rest before rapid weight loss $(p<0.001)$, but a significant difference was found compared to values of $5^{\text {th }}$ sequence. We also note a significant variation in plasma volume after the bouts of session 11 in the direction of hemodilution $(p<$ 0.05). Other basal blood parameters were not affected by the intervention if we compared our values between $\mathrm{JFS}_{1}$ to $\mathrm{JFS}_{11}$.

\section{Discussion}

To our knowledge, the effects of rapid weight loss on judo-energy profile, specific performance and haematological parameters in Subsaharan African envi- 
ronment has been not investigated so far. The major findings of our study indicate that RWL increases heart rate during fights, decreases motor performance in judo (number of uchi-komi executed during a field event, body placement) and haematological values compared to baseline values. Weight loss practices are at the heart of the judo practice in competition, the proportion of fighters having regular recourse to them being very important (Artioli et al., 2010). Rapid weight loss, that is to say carried out in less than 10 days, is also significant (Franchini et al., 2012). There are many methods which are identified by Brito et al. (2012) and are not always in agreement with the search for optimal performance. In our study, one of the methods identified is the restriction of food intake (61\% of respondents during the interviews). Among the other methods cited, we find the drastic restriction of nutritional intake (35\% of respondents), or even total the last days of weight loss; this suggests an exhaustion of energy reserves. Thus, the increase in energy expenditure (17\%) during training sessions, associated with the practice of long joggings, goes completely against the sharpening process (reduction in training volume, maintenance or increase in intensity with the aim of improving performance) which is sought after in the pre-competitive period. Finally, the methods dictated by a restriction of water intake ( $20 \%$ of our respondents) coupled with a search for excessive sweating (5\% of citations) can lead, if they are practiced excessively, to a state of dehydration, obviously bad for performance. In fact, some responses, which are very much in the minority, report long and/or almost total restriction with a mass loss objective well above $2 \%$, which beyond the risk of performance, represents generally a health risk (Artioli et al., 2016).

Regarding the energy expenditure during the different phases of a training session and evaluated using the $\mathrm{HR}_{\max }$ reached, our results show that the anaerobic energy expenditure and cardiac solicitation in real judo practice situations are important throughout weight loss. Our results in judoists subjected to combined training with a RWL show at the end of the warm-up average values of $117 \pm 10 \mathrm{bpm}$, with range of $97 \mathrm{bpm}-123 \mathrm{bpm}$ (Figure 2). The interest of the telemetric study of the HR in the evaluation of energy expenditure during training in combat sports is underlined by several studies (Guillerme, 2014; Francescato et al., 1995; Majean et al., 1990). Among the studies that we found in the literature concerning judoists, Ahmaidi et al. (2005) report a mean frequency of $150 \pm 10 \mathrm{bpm}$ during the warm-up phase, a value higher than that found by Selinger (2014) $143 \mathrm{bpm}$ for HR between 132 - $151 \mathrm{bpm}$ without specifying the level of the judoists, their physical condition, the conditions and the level of stake. At the end of the judo fights, the $\mathrm{HR}_{\max }$ recorded in our study were $180.5 \pm$ $4.9 \mathrm{bpm}$ at session $\mathrm{S}_{11}$ against $171.4 \pm 5.2 \mathrm{bpm}$ at session $\mathrm{S}_{1}$ (i.e. a difference of $5 \% ; p<0.05$, Figure 3 ). In the only study that we identified in the literature in combat sports athletes subjected to RWL, that of Yang et al. (2018) devoted to taekwondo, the authors note at the end of the series of fights ( 5 fights per series and a number of 3 series) values of: $179.6 \pm 10.9 \mathrm{bpm}$ at the end of the first series 
(maximum: $193.3 \pm 8.3 \mathrm{bpm}$ ), $176.8 \pm 8.7 \mathrm{bpm}$ in the second set (maximum: $188.6 \pm 5.4 \mathrm{bpm}$ ) and $185.8 \pm 3.2 \mathrm{bpm}$ in the third set (maximum: $196.2 \pm 5.0$ bpm); i.e. a variation of $4.8 \%$. Ahmaidi et al. (2015), in judoists not subjected to a RWL report at the end of 3 min of fight for 3 series (each including 3 fights) of $\mathrm{HR}_{\max }$ of: $125 \pm 9 \mathrm{bpm}$ for series $1,161 \pm 10 \mathrm{bpm}$ for series 2 and $163 \pm 8 \mathrm{bpm}$ for series 3 ; i.e. a mean increase of $23 \%$.

Regarding the number of uchi-komi before and after RWL during the sessions (Figure 4), it decreased significantly. For Almansba et al. (2007), uchi-komi number is the main variable determining test performance. Also, quantity is inseparable from quality. And we also observe that the height $\mathrm{H}$ to which uke's center of gravity is raised, which can be considered as representative on the one hand of the quality of technical execution, but also on the other hand of the general anaerobic alactic power of each technical repetition also decreases significantly at the end of the test (Figure 5). The gradual and significant decrease in the number of uchi-komi performed by Tori and the height of Uke's center of gravity, from session 1 to session 11, therefore suggests a deterioration in muscle strength due to a greater level of physical fatigue. As a result of dehydration, therefore a weight loss. This difference could be explained by the fact that for high intensity activity during the performance test lasting 30 minutes 40 , the body mainly uses the process of anaerobic glycolysis. This system uses water to help synthesize energy, to resynthesize pyruvate into glucose. Water is used by the aerobic system to perform the same role. An organism with limited water may decrease the ability of anaerobic, lactic and aerobic glycolytic processes to produce energy, and thus negatively affect performance (Carlton \& Orr, 2015). Our results, which thus show, as in taekwondo, an alteration in the processes of the metabolic systems, undoubtedly reflect the decrease in the intensity of movements including the times of rest and stops of the performed movements (Santos et al., 2011; Bridge et al., 2013; Hausen et al., 2017). Our observations strongly agree with the fact that the aerobic system is used during long-duration moderate intensity movements, while the lactic anaerobic system is less required (Mader, 2003). Similar results are reported by Marcon et al. (2010) in judo which show that the aerobic system is used frequently (66\%) during fights. However, only the evaluation of fat and muscle mass throughout the program can make it possible to objectify these statements, even if it is reported that the more intense the calorie restriction, the greater the loss of muscle mass in the loss of body mass (Leibel et al., 1995). As muscle atrophy results in a significant loss of contractile proteins (Horswill et al., 1990), muscle strength decreases (Walberg et al., 1988) consequently in proportion to this loss (Narici et al., 1989).

As for the haematological parameters, these give some indication of body dehydration status. For example, MCHC significantly describes the cellular viscosity of blood within RBC (Bull et al., 1996), and the increase in hematocrit reflects the negative influence of blood viscosity. In our study, the alteration of these parameters (Table 4 ) is associated with the reduction in motor performance be- 
cause the increase in viscosity reduces peripheral blood flow and cardiac output (Connes et al., 2013; Brun et al., 2012; Mcardle et al., 2010). The increase in hematocrit in athletes, especially in our judoists, may be due to the extensive loss of body water during intensive training and water restrictions (Brun et al., 2000). Concerning the significant increase (13.4\%) of plasma volume changes, our observations join those of Vaccaro et al. (1976) through the physiological alterations that can induce a loss of water greater than $4 \%$ of the body mass, which lead to significant changes in physical ability. However, they are contrary to those of other authors who observe hemoconcentration and for whom body water loss > 3\% body mass does not affect plasma volume (Yang et al., 2017; Francesconi et al., 1987; Armstrong et al., 1998). The discrepancy between our results and those of the literature is mainly explained by the protocol and the nutritional disorders linked to the poor living conditions of most of our subjects. Regarding the protocol for example, in our study the subjects are judoists who performed, in addition to physical preparation exercises and technical-tactical training, 30 to 50 fights of 3 - 5 minutes each and divided into $51 / 2$ days. On the other hand, the subjects of Yang et al. (2018) are taekwondo athletes and the duration of RWL is $31 / 2$ days. Blood samples were taken after the series of fights in sessions 1 and 11 in our work, while they were taken 16 hours after competition day in Yang's study. In this case, athletes recovered their body water and carbohydrates storage. In addition, the time between each serie of fights taekwondo bouts was 1 hour compared to 5 minutes for us, the duration of a fight being 2 minutes versus 3 - 5 minutes in our study. The hypervolemia observed in our work can then be explained by an increase in the level of intravascular water probably due to retention of both proteins and electrolytes under hormonal control. Indeed, after endurance exercises such as those implemented in our training schedule, the intravascular protein mass increases, thereby inducing hypervolemia. The mechanism responsible for the content is not yet entirely clear. However, when the total protein concentration increases by food manipulation for 4 days, the plasma volume does not change (Leiper et al., 1988). This implies that proteins are not the only ones responsible for the expansion of plasma volume.

In addition, during physical exertion, changes in renal perfusion and hormonal variations promote fluid retention. Thus, the increase in plasma volume and that of extravascular fluids is favored by limiting fluid loss: 1) through redistribution of blood in favor of the working muscles; 2) thanks to the activation of the renin-angiotensin-aldosterone system (Milledge et al., 1982; Makni Krichen et al., 2009) which induces a retention of $\mathrm{Na}^{+}$, and thereby a displacement of fluids towards the circulation (Leiper et al., 1988); 3) by stimulating the hormones responsible for the hydroelectric balance (ADH, FAN, aldosterone, renin); 4) and also through metabolic water production through the oxidation of fatty acids and carbohydrates and the release of water from glucose stored in muscle and liver (Pastene et al., 1996). 
Our results show also that the hematocrit was higher at the end of session $S_{1}$ compared to session $S_{11}$ (Table 4). Hematocrit is affected by a variety of factors including hydration status and the above-mentioned mechanisms, which could exert an influence on values. Besides $\mathrm{MCH}, \mathrm{MCHC}$ and hematocrit, other blood values were also no affected by the intervention. In regard of RBC deformability, $\mathrm{MCV}$ is of special interest. A decrease in RBC might be caused by food restriction during RWL.

Numerous studies associated a reduction in RBC to decrease in blood glucose and thus reduced a reduced ATP level (Henkelman et al., 2010; Grau et al., 2013). A study of Yang et al. (2015) indicated that food restriction and reduced glucose levels reduce nitric oxide production in RBC which in turn reduces RBC deformability. It remains to be investigated whether RWL facilitates oxidative/nitrosative stress which was show to reduce RBC. Finally, our results show a significant increase in lactatemia from the first to the eleventh session, $S_{1}-S_{11}$ (Table 4). The predominance of the anaerobic lactic component during training sessions is thus verified by the high concentrations of blood lactates, exceeding $10 \mathrm{mmol} / \mathrm{L}$. The higher values are for judoists less than $100 \mathrm{~kg}$. These observations are in line with field analyzes by Chance et al. (1987) which show that enduring judoists possess superior aerobic qualities, underlining once that the resynthesis of phosphocreatine (PC) is linked to the oxidative metabolism. On the other hand, there is a more significant intervention of anaerobic glycolysis during the transitional phase of adaptation to each workload in judoists with an explosive profile. These have a less efficient mitochondrial system, the resynthesis of PC is slower; this does not allow them to maintain high power for long, from where they usually win their fights at the onset of assaults.

Thus, analysis of our results leads us to draw some recommendations for judo competitors and coaches as part of an overall sports preparation. Indeed, our results show that judoists are not recommended to cut weight before competitions. Before a judoist decides alone or in agreement with his trainer to undertake a rapid weight loss regimen to change weight category, it is advisable to seek the advice of a doctor and a dietitian in order to study the feasibility, ins and outs of such a maneuver. In all cases, it is better to favor gradual or progressive loss over emergency or rapid loss through dehydration, so as not to lose 1 $\mathrm{kg} /$ week to limit the loss of muscle strength. If the quick method is being considered, you should avoid losing more than $4 \%$ of your body mass. To do this, from a nutritional point of view, the judoist must eat in the following caloric proportions: $60 \%$ to $65 \%$ carbohydrates; $15 \%$ to $20 \%$ proteins; $20 \%$ lipids, to curb the inevitable involutions of body composition and motor performance. An intake of $4 \mathrm{~g} / \mathrm{kg} / \mathrm{d}$ of carbohydrates is necessary. The lipid intake should not be lowered below $20 \%$, because essential fatty acids remain essential for the proper functioning of the body and therefore for health. Hence, it is imperative to have the nutritional value of the main foods commonly consumed in the Congo. After the weigh-in, a carbohydrate load (i.e., meal containing $200-300 \mathrm{~g}$ of $\mathrm{CHO}$ ) is 
recommended. In terms of training, the final preparation of the judoist (last month) must respect the general principle of training by reducing the content of the session, and therefore their duration. If an endurance activity must be undertaken for the purpose of weight loss, certain principles should be observed: sessions should not exceed 30 minutes, and small accelerations at the end of the session are advisable. For example, in the last 10 days of the diet, two short training sessions (30 to $40 \mathrm{~min}$ ) are done twice a day or are combined with one long session (1 $1 / 2$ to 2 hours) of judo training. Depending on the state of fatigue, a single session may be sufficient (especially for rapid weight loss). Despite the slight impact on physical capacity, rapid weight loss has negative effects on several health parameters. In addition, competitive performance may be impaired, since other factors (e.g., mood profile and cognition) associated with competitive performance (no objective in this study) are impaired. In sum, RWL should especially be avoided if the judoist will knowingly have less than 3 hours to refeed and rehydrate after the weigh-in. Indeed, if the dehydration is greater than $4 \%$ of the body mass and if the time between weighing and the start of the competition is less than 5 hours, the athlete's physical capacities are in all cases altered, even if in the meantime a fluid intake more than covered the loss. Therefore, only relevant weight loss strategies can maintain the performance capabilities of the judoist. On the other hand, the transgression of certain principles such as those mentioned above is enough to alter these performance capacities and (or) his health.

However, it is important to note some limitations of this study. The first limitation is the assessment of energy expenditure. It would have been desirable to separately determine the aerobic, anaerobic lactic and anaerobic alactic systems by the consumption of $\mathrm{O}_{2}$ during a session, combined with measurements of maximum lactate concentration and the fast of excess oxygen uptake after exercise (EPOCFAST), as suggested by a recent study of Yang et al. (2018). However, the implementation of these methods is proving difficult in the context of the poor technical facilities of our biological analysis laboratories. A second limitation is related to the fact that the magnitude of the performance deleteriousness of the subsequent water loss to the rapid weight loss could be minimized by the fact that the performance test used in this work is not perfectly representative of competition in judo. Indeed, it representatively simulates a judo fight, in an isolated way. However, performance in competition requires a series of combats to achieve a ranking. In this case, the very significant decrease in performance at the end of session 11 is accentuated if the test consisted of a sequence of fights. It would therefore have been desirable to set up a protocol that is truly representative of a competition. For example, a protocol requiring the performance test used here to be completed 6 times, each test performed being separated by a 20 to 30 minutes rest period, as is the case in official competitions. Therefore, it can be suggested that rapid weight loss is even more deleterious to competition performance than the results would suggest. The third limitation is inaccuracies of 
measurement which might also explain the high hematocrit results and might thus represent a possible limitation of the study. Finally, the fourth limitation of our study relates to information on rapid weight loss practices used by our subjects who relied only on their statements, without rigorous verification; this does not authorize the generalization of the conclusions obtained to the entire population of Congolese competitive judoists.

It is suggested that future investigations on judo RWL effects who must take these limits into account verify if repeat RWLs of structured training protocols and includes sparring fights and official fights, lead to different results in the season.

\section{Conclusion}

Our results suggest that RWL in judo at about $4 \%-5.5 \%$ of body mass has a negative effect on the body, even if a period is allowed for rehydration; each variable determining performance having varied negatively. For this, it is necessary to favor longer and progressive weight losses, so as not to associate the possible negative consequences, and not to disrupt the training process. It would also be interesting to respond to the problem represented by the general ignorance of competitive judoists and coaches, especially in black African circles, in terms of nutrition by making them aware of the importance of this aspect for sporting performance. It is in this context that to protect judoists health situation, African Judo Federations through the African Judo Union, particularly Congolese Judo Federation should be considered a random control of body weight in the morning of the competition day to ensure no discrepancy of body weight between weigh-in and competition day.

\section{Acknowledgements}

The authors thank Francine KIBONGUI, Alexis ILOKI, and Arthur LOUYA for their assistance in blood collection and the subjects.

\section{Author's Contribution}

Study concept and design: MOULONGO JGA and MASSAMBA A; Acquisition of data: MOUSSOUAMI SI, MOUSSOKI JM, MASSALA KITANGA FN, and MOULONGO NGWALLAT JAP; Methodology: MASSAMBA A and PACKA TCHISSAMBOU B; Investigation: MOULONGO JGA, BUESO NZAMBI GA, ATA ASIOKARAH NF, and DIAGNE OSSEY M; Analysis and interpretation of data: MASSAMBA A, MOULONGO JGA, and PACKA TCHISSAMBOU B; Drafting of manuscript: all authors; Critical revision of the manuscript: all authors; Statistical analysis: MASSAMBA A; Administrative, technical, and material support: MOULONGO JGA, MASSAMBA A, ATA ASIOKARAH NF, and MASSALA KITANGA NF; Study supervision: MASSAMBA A.

\section{Conflicts of Interest}

The authors declare no conflicts of interest regarding the publication of this paper. 


\section{References}

Ahmaidi, S., Portero, P., Calmet, M., Lantz, D., Vat, W., \& Libert, J. P. (2005). Bioenergétique et échanges cardiorespiratoires lors de deux situations de combat en judo et en kendo. Communication au Congrès de la Fédération Européenne de Judo, Pamplume, 2005, 55-60.

Almansba, R., Franchini, E., \& Sterkowicz, S. (2007). Uchi-komi avec charge, une approche physiologique d'un nouveau test spécifique au judo. Science \& Sports, 22, 216-223. https://doi.org/10.1016/j.scispo.2007.06.006

Armstrong, L. E., Soto, J. A., Hacker, F. T. Jr., Casa, D. J., Kavouras, S. A., \& Maresh, C. M. (1998). Urinary Indices during Dehydration, Exercise, and Rehydration. International Journal of Sport Nutrition and Exercise Metabolism, 8, 345-355. https://doi.org/10.1123/ijsn.8.4.345

Artioli, G. G., Gualano, B., Franchini, E., Seagliusi, F. B., Takesian, M., Fuchs, M., \& Lancha, A. H. Jr. (2010). Prevalence, Magnitude, and Methods of Rapid Weight Loss among Judo Competitors. Medicine \& Science in Sports \& Exercise, 42, 436-442. https://doi.org/10.1249/MSS.0b013e3181ba8055

Artioli, G. G., Saunders, B., Iglesias, R. T., \& Franchini, E. (2016). It Is Time to Ban Rapid Weight Loss from Combat Sports. Sports Medicine, 46, 1579-1584. https://doi.org/10.1007/s40279-016-0541-x

Bridge, C. A., Mc Naughton, L. R., Close, G. L., \& Drust, B. (2013). Taekwondo Exercise Protocols Do Not Recreate the Physiological Responses of Championship Combat. International Journal of Sports Medicine, 34, 573-581. https://doi.org/10.1055/s-0032-1327578

Brito, C. J., Roas, A. F., Brito, I. S., Marins, J. C., Cordova, C., \& Franchini, E. (2012). Methods of Body Mass Reduction by Combat Sport Athletes. International Journal of Sport Nutrition and Exercise Metabolism, 22, 89-97. https://doi.org/10.1123/ijsnem.22.2.89

Brun, J. F., Bouchahda, C., Chaze, D., Benhaddad, A. A., Micallef, J. P., \& Mercier, J. (2000). The Paradox of Hematocrit in Exercise Physiology Which Is the "Normal" Range from an Hemorheologist's View Point? Clinical Hemorheology and Microcirculation, 22, 287-303.

Brun, J. F., Varlet-Marie, E., \& Raynaud de Mauverger, E. (2012). Relationships between Insulin Sensitivity Measured with the Oral Minimal Model and Blood Rheology. Clinical Hemorheology and Microcirculation, 51, 29-34. https://doi.org/10.3233/CH-2011-1426

Bull, B. S., Aller, R., \& Houwen, B. (1996). MCHC-Red Cell Index OR Quality Control Parameter. Haematology, 43, 43.

Caldwell, J. E., Ahonen, E., \& Nousiainen, U. (1984). Differential Effects of Sauna-, Diuretic-, and Exercise-Induced Hypohydratation. Journal of Applied Physiology, 57, 1018-1023. https://doi.org/10.1152/jappl.1984.57.4.1018

Carlton, A., \& Orr, R. M. (2015). The Effects of Fluid Loss on Physical Performance: A Critical Review. Journal of Sport and Health Science, 4, 357-363. https://doi.org/10.1016/j.jshs.2014.09.004

Chance, B., Leigh, J. S., Clark, B. J., Maris, J., Kent, J., Nioka, S., \& Smith, D. (1995). Control of Oxidative Metabolism and Oxygen Delivery in Human Skeletal Muscle: A Steady-State Analysis of the Work Energy Cost Transfer Function. Proceedings of the National Academy of Sciences of the United States of America, 82, 8384-8388. https://doi.org/10.1073/pnas.82.24.8384 
Choma, C. W. (1998). The Effects of Rapid Weight Loss on Cognitive Function in Collegiate Wrestlers. Medicine \& Science in Sports \& Exercise, 30, 746-749. https://doi.org/10.1097/00005768-199805000-00016

Connes, P., Simmonds, M. J., Brun, J. F., \& Baskurt, O. K. (2013). Exercise Hemorheology: Classical Data, Recent Findings and Unresolved Issues. Clinical Hemorheology and Microcirculation, 53, 187-199. https://doi.org/10.3233/CH-2012-1643

Costill, D. L., Cote, R., \& Fink, W. (1976). Muscle Water and Electrolytes Following Varied Levels of Dehydration in Man. Journal of Applied Physiology, 40, 6-11. https://doi.org/10.1152/jappl.1976.40.1.6

Degoutte, F., Jouanel, P., Begue, R. J., Colombier, M., Lac, G., Pequignot, J. M., \& Filaire, E. (2006). Food Restriction, Performance, Biochemical, Psychological, and Endocrine Changes in Judo Athletes. International Journal of Sports Medicine, 27, 9-18. https://doi.org/10.1055/s-2005-837505

Dill, D. B., \& Costill, D. L. (1974). Calculation of Percentage in Changes in Volumes of Blood, Plasma, and Red Cells in Dehydration. Journal of Applied Physiology, 37, 247-248. https://doi.org/10.1152/jappl.1974.37.2.247

Favre-Juvin, A., Majean, H., Gaillat, L., Callec, C., \& Eterradossi, J. (1989). Approche physiologique du judo. Sport Médecine Actualités, 4, 5-10.

FECOJU (2018). Statistiques fédérales des licenciés de la Fédération Congolaise de Judo, année sportive 2018. Brazzaville: Direction Générale des Sports.

Fogelholm, M. (1994). Effects of Body Weight Reduction on Sports Performance. Sports Medicine, 18, 249-267. https://doi.org/10.2165/00007256-199418040-00004

Fogelholm, M., Koskinen, R., Laakso, J., Rankinen, T., \& Ruokonen, I. (1993). Gradual and Rapid Weight Loss: Effects on Nutrition and Performance in Male Athletes. Medicine \& Science in Sports \& Exercise, 25, 371-377. https://doi.org/10.1249/00005768-199303000-00012

Francescato, M. P., Talon, T., \& di Prampero, P. E. (1995). Energy Cost and Energy Source in Karate. European Journal of Applied Physiology, 71, 355-361. https://doi.org/10.1007/BF00240417

Francesconi, R. P., Hubbard, R. W., Slyk, P. C., Schnakenberg, D., Carlson, D., Leva, N. et al (1987). Urinary and Hematologic Indexes of Hypohydration. Journal of Applied Physiology, 62, 1271-1276. https://doi.org/10.1152/jappl.1987.62.3.1271

Franchini, E., Brito, C., \& Artioli, G. G. (2012). Weight Loss in Combat Sports: Physiological, Psychological and Performance Effects. Journal of the International Society of Sports Nutrition, 9, 52-58. https://doi.org/10.1186/1550-2783-9-52

Franchini, E., Del Vecchio, F. B., Matsushigue, K. A. et al. (2011a). Physiological Profiles of Elite Judo Athletes. Sports Medicine, 41, 147-166. https://doi.org/10.2165/11538580-000000000-00000

Franchini, E., Sterkowicz, S., Szmatlan-Gabrys, U. et al. (2011b). Energy System Contributions to the Special Judo Fitness Test. International Journal of Sports Physiology and Performance, 6, 334-343. https://doi.org/10.1123/ijspp.6.3.334

Gariod, L., Favre-Juvin, A., Novel, Y., Reutenaeuer, H., Majean, H., \& Rossi, A. (1995). Evaluation du profil énergétique des judokas par spectroscopie $\mathrm{RMN}$ du $\mathrm{P}^{31}$. Science \& Sports, 10, 201-207. https://doi.org/10.1016/0765-1597(96)89370-1

Grau, M., Pauly, S., Ali, J., Walpurgis, K., Thevis, M., Bloch, W. et al. (2013). RBCNOS-Dependent S-Nitrosylation of Cytoskeletal Proteins Improves RBC Deformability. PLoS ONE, 8, e56759. https://doi.org/10.1371/journal.pone.0056759 
Green, C. M. (2007). Injuries among Judokas during Competition. Scandinavian Journal of Medicine \& Science in Sports, 17, 205-210.

Guillerme, P. L. (2014). Evolution de la fréquence cardiaque au cours des différentes activités sportives. Thèse de médecine, Toulouse, 1996.

Gutierrez-Garcia, C., Perez Gutierez, M., \& Svinoh, J. (2010). Martial Arts of the World: An Encyclopedia of Historic and Innovation (Vol. 1, pp. 181-191). Santa Barbara, CA: ABC-Clio.

Hausen, M., Soares, P. P., Araijo, M. P., Porto, F., Franchini, E., Bridge, C. A. et al. (2007). Physiological Responses and External Validity of a New Setting for Taekwondo Combat Simulation. PLOS ONE, 12, e0171553. https://doi.org/10.1371/journal.pone.0171553

Henkelman, S., Dijkstra-Tiekstra, M. J., de Wildt-Eggen, J., Graaff, R., Rakhorst, G., \& Van Coveron, W. (2010). Is Red Blood Cell Rheology Preserved during Routine Blood Bank Storage? Transfusion, 50, 941-948. https://doi.org/10.1111/j.1537-2995.2009.02521.x

Horswill, C. A., Park, S. H., \& Roemmich, J. N. (1990). Changes in the Protein Nutritional Status of Adolescent Wrestlers. Medicine \& Science in Sports \& Exercise, 22, 599-604. https://doi.org/10.1249/00005768-199010000-00010

IJF (2020). La Fédération Internationale de Judo est fondée en 1951. Le judo fait ses débuts olympiques aux jeux de Tokyo en 1964. http://www.ijf.org

Klissouras, V. (2017). Les bases de la physiologie du sport, 64 concepts clés. Paris: Elsevier/Masson.

Koral, J., \& Dosseville, F. (2009). Combination of Gradual and Rapid Weight Loss: Effects on Physical Performance and Psychological State of Elite Judo Athletes. Journal of Sports Sciences, 27, 115-120. https://doi.org/10.1080/02640410802413214

Leibel, R. L., Rosenbaum, M., \& Hirsch, J. (1995). Changes in Energy Expenditure Resulting from Altered Body Weight. New England Journal of Medicine, 332, 621-628. https://doi.org/10.1056/NEJM199503093321001

Leiper, J. B., Mc Cormick, J. D., Robertson, J. D., Withing, Ph., \& Maughan, R. G. (1988). Fluid Homeostasis during Prolonged Low-Intensity Walking on Consecutive Days. Clinical Science, 75, 63-70. https://doi.org/10.1042/cs0750063

Mader, A. (2003). Glycolysis and Oxidative Phosphorylation as a Function of Cytosolic Phosphorylation State and Power Output of the Muscle Cell. European Journal of Applied Physiology, 88, 317-338. https://doi.org/10.1007/s00421-002-0676-3

Maillat, H., \& Gaillat, L. (1986). Etude de l'acide lactique sanguin chez le judoka en fonction des méthodes d'entraînement. Médecine du Sport, 60, 194-197.

Majean, H., Gaillat, L., Callec, C., Eterradossi, J., \& Favre-Juvin, A. (1990). Approche physiologique du judo. Sport et Médecine, 49, 28-32.

Makni Krichen, O., Adonon, S., Lounana J., Hmani, S., Medelli, J., \& Dine, G. (2009). Effet des variations de volume plasmatique sur les paramètres sanguins après une succession d'exercices de longue durée. Biotribune, 31, 20-24.

https://doi.org/10.1007/s11834-009-0115-4

Marcon, G., Franchini, E., Jardin, J. R., \& Barros Neto, T. L. (2010). Structural Analysis of Action and Time in Sports: Judo. Journal of Quantitative Analysis in Sports, 6, 1-15. https://doi.org/10.2202/1559-0410.1226

Mcardle, W. D., Katch, F. I., \& Katch, V. L. (2010). Exercise Physiology: Nutrition, Energy, and Human Performance. Princeton, NJ: Lippincott Williams \& Wilkins.

Miarka, B., Leme Gonçalves, P. V., Ferreira, J. U., Boscolo Del Vechio, F., Calmet, M., \& 
Franchini, E. (2012). A Comparison of Time-Motion Performance between Age Groups in Judo Matches. Journal of Sports Sciences, 30, 899-905. https://doi.org/10.1080/02640414.2012.679675

Milledge, J. S., Bryson, E. I., Catley, D. M. et al. (1982). Sodium Balance, Fluid Homeostasis and the Renin Aldosterone System during the Prolonged Exercise of Hill Walking. Clinical Science, 62, 595-604. https://doi.org/10.1042/cs0620595

Muller Deck, H. (1987). Theoretische prositionen und praktische logsungsätche zun situations training als prinzi pielle methode des technisch-taküschen trainings in judo (teil 1). Theorie und Praxis der Köperkultur, 2, 105-111.

Narici, M. V., Roi, G. S., Landoni, L., Minetti, A. E., \& Cerretelli, P. (1989). Changes in Force, Cross-Sectional Area and Neural Activation during Strength Training and Detraining of the Human Quadriceps. European Journal of Applied Physiology and Occupational Physiology, 59, 310-319. https://doi.org/10.1007/BF02388334

Oppliger, R. A., Case, H. S., Horswill, C. A., Landry, G. L., \& Shelter, A. C. (1996). American College of Sport Medicine Position Stand. Weight Loss in Wrestlers. Medicine \& Science in Sports \& Exercise, 28, 9-12. https://doi.org/10.1097/00005768-199610000-00049

Paillard, T. (2010). Optimisation de la performance sportive en judo. Paris: Editions De Boeck.

Pastene, J., Germain, M., Allevard, A. M. et al. (1996). Water Balance during and after Marathon Running. European Journal of Applied Physiology and Occupational Physiology, 73, 49-55. https://doi.org/10.1007/BF00262808

PNUD (2018). Rapport annuel sur le développement durable en République du Congo. Année 2018. Brazzaville: Représentation nationale du Programme des Nations Unies pour le Développement.

Pocecco, E., \& Burtscher, M. (2013). Sex Differences in Response to Arm and Led Ergometry in Juvenile Judo Athletes. Archives of Budo, 9, 181-187.

Redman, L. M., Heilbronn, L. K., Martin, C. K., Alfonso, A., Smith, S. R., \& Ravissin, E. (2007). Effects of Calorie Restriction with or without Exercise on Body Composition and Fat Distribution. The Journal of Clinical Endocrinology \& Metabolism, 92, 865-872. https://doi.org/10.1210/jc.2006-2184

Reljic, D., Feist, J., Jost, J., Kieser, M., \& Friedmann-Bette, B. (2016). Rapid Body Mass Loss Affects Erythropoiesis and Hemolysis But Does Not Impair Aerobic Performance in Combat Athletes. Scandinavian Journal of Medicine \& Science in Sports, 26, 507-517. https://doi.org/10.1111/sms.12485

Santos, V. G., Franchini, E., \& Lima-Silva, A. E. (2011). Relationship between Attack and Skipping in Taekwondo Contests. The Journal of Strength and Conditioning Research, 25, 1743-1751. https://doi.org/10.1519/JSC.0b013e3181ddfb0f

Sawka, M. N., \& Pandolf, K. B. (1990). Effects of Body Water Loss on Physiological Function and Exercise Performance. In C. W. Gisolfi, \& D. R. Lamb (Eds.), Perspectives in Exercise Science and Sports Medicine (Vol. 3, pp. 1-38). Carmen: Benchmark Press.

Schaffter, O. (2004). L'influence d'une perte de poids sur la performance. Travail de diplôme pour l'obtention du diplôme de maître de sport HESS, Haute Ecole Spécialisée Fédérale de Sport. Macolin, Suisse.

Selinger, G. (2014). Etude télémétrique de la fréquence cardiaque et suivi médical de judokas Camerounais. Travaux et Recherches, 37, 185-208.

Serfass, R. C., Stull, G. A., Alexander, J. F., \& Ewing, J. L. Jr. (1984). The Effects of Rapid Weight Loss and Attempted Rehydration on Strength and Endurance of the 
Hand-Gripping Muscles in College Wrestlers. Research Quarterly for Exercise and Sport, 55, 46-52. https://doi.org/10.1080/02701367.1984.10605354

Shephard, R. J., \& Shek, P. N. (1995). Heavy Exercise, Nutrition and Immune Function: Is There a Connection? International Journal of Sports Medicine, 16, 491-497. https://doi.org/10.1055/s-2007-973043

Sokal, R. F., \& Rohlf, S. W. (1995). Biometry (7th ed.). San Francisco, CA: Freeman and Co.

Vaccaro, P., Zauner, C., \& Cade, J. (1976). Changes in Body Weight, Hematocrit and Plasma Protein Concentration Due to Dehydration and Rehydration in Wrestlers. The Journal of Sports Medicine and Physical Fitness, 16, 45. https://doi.org/10.1249/00005768-197500710-00065

Viitasalo, J. T., Kyrolainen, H., Bosco, C., \& Alen, M. (1987). Effects of Rapid Weight Reduction on Force Production and Vertical Jumping Height. International Journal of Sports Medicine, 8, 281-285. https://doi.org/10.1055/s-2008-1025670

Walberg, J. L., Leidy, M. K., Sturgill, D. J., Hinkle, D. E., Ritchey, S. J., \& Sebolt, D. R. (1988). Macronutriment Content of a Hypoenergy Diet Affects Nitrogen Retention and Muscle Function in Weight Lifters. International Journal of Sports Medicine, 9, 261-266. https://doi.org/10.1055/s-2007-1025018

Webster, S., Rutt, R., \& Weltman, A. (1990). Physiological Effect of a Weight Loss Regimen Practiced by College Wrestlers. Medicine \& Science in Sports \& Exercise, 22, 229-234.

WHO Regional Office for Africa (2018). Atlas of African Health Statistics 2018. Universal Health Coverage and the Sustainable Development Goals in the WHO African Region. Brazzaville: WHO Regional Office for Africa.

Yang, W. H., Heine, O., \& Grau, M. (2018). Rapid Weight Reduction Does Not Impair Athletic Performance of Taekwondo Athletes: A Pilot Study. PLOS ONE, 13, e0196568. https://doi.org/10.1371/journal.pone.0196568

Yang, W. H., Heine, O., Mester, J., \& Grau, M. (2017). Impact of Rapid Weight Reduction on Health and Performance Related Indicators of Athletes Representing the Olympic Combat Sports. Archives of Budo, 13, 147-160. https://doi.org/10.1371/journal.pone.0196568

Yang, W. H., Heine, O., Pauly, S., Kim, P., Bloch, W., Mester, J. et al. (2015). Rapid Rather than Gradual Weight Reduction Impairs Hemorheological Parameters of Taekwondo Athletes through Reduction in RBC-NOS Activation. PLoS ONE, 10, e0123767. https://doi.org/10.1371/journal.pone.0123767 